\title{
Textbooks, Teaching and Evaluation: An Analysis on the Three Elements of the Rule of Law Education in Ideological and Political Courses of Middle School
}

\author{
Zhiyu Cao ${ }^{1, *}$
}

\author{
${ }^{1}$ Jingdezhen University, Jingdezhen, Jiangxi 333000, China \\ *Corresponding author. Email:41712916@qq.com
}

\begin{abstract}
Middle school is a key link in the development of rule of law education for young people, and ideological and political course is the main way of rule of law education in middle schools. The rule of law education in ideological and political courses of middle school mainly includes two parts: imparting legal knowledge and cultivating the awareness of rule of law. The three elements of textbooks, teaching and evaluation constitute the closed loop of the procedure of general courses, which are the cut-in ideas for strengthening and perfecting the rule of law education in ideological and political courses of middle school. On the one hand, teachers should fully sort out and use textbooks as the main carrier to achieve systematic teaching goals. On the other hand, teachers should comprehensively use a variety of teaching methods to improve teaching effects, and improve teaching capabilities through learning and training. Finally, the scientific evaluation system should be studentcentered.
\end{abstract}

Keywords: Middle school, Rule of law education, Ideological and political courses.

\section{INTRODUCTION}

Adolescents are the builders and successors of socialism in the future, as well as the practitioners and promoters of the strategy of comprehensively ruling the country according to law. At the Fourth Plenary Session of the 18th CPC Central Committee, it proposed to "bring rule of law education into the national education system, start with teenagers and set up rule of law courses in primary and secondary schools". On June 28, 2016, the Ministry of Education and the Ministry of Justice jointly issued and implemented the "outline of rule of law education for adolescents", which provided a fundamental basis for promoting the integration of rule of law education into the national education system and improving the rule of law education for adolescents in schools. Generally speaking, middle school students refer to adolescents aged from 12 years old to 18 years old who are in the transition period from children to adults. Based on the strong plasticity of these adolescents, the middle school stage is a key period for them to form a correct world outlook, outlook on life and values, and is also a key link in developing rule of law education for adolescents. Middle school is the main place for students to study and live, and the rule of law education for teenagers is mainly implemented through ideological and political courses. According to the law of physical and mental development of middle school students, the ideological and political courses aim to promote middle school students to form positive thoughts, psychology and behavior.

Middle school students generally develop rapidly, their physical characteristics are close to that of adults, but their minds are not mature, their self-control and discrimination abilities are weak, and they are vulnerable to adverse external factors. Therefore, schools should guide and standardize the behavior of middle school students through rule of law education, cultivate their rational and independent social adaptability, and help middle school students put legal knowledge into practice. At present, in the research of rule of law education in ideological and political course of middle schools, the pertinence and practicality of the existing results is insufficient due to the 
particularity of the research objects and the professionalism of researchers and other factors. In view of this, starting from the closed loop program of general curriculum, this paper analyzes the three elements of textbooks, teaching and evaluation, so as to provide ideas for strengthening and improving the rule of law education in ideological and political course of middle schools.

\section{PROBLEMS IN RULE OF LAW EDUCATION IN IDEOLOGICAL AND POLITICAL COURSES OF MIDDLE SCHOOLS}

There are two parts of imparting legal knowledge and cultivating the awareness of rule of law in the rule of law education in ideological and political courses of middle schools. In the context of comprehensively promoting law-based governance in the new era, in response to social changes and the needs of the times, the ideological and political courses in middle schools highlight the important position of rule of law education, pay more attention to constitutional education, juvenile protection education and related rights and compulsory education, and focus on the protection of teenagers' rights, achieving remarkable progress. However, in the actual development process, there are some problems in the aspects of textbooks, teaching and evaluation in the rule of law education in ideological and political education of middle schools.

\subsection{The Realization of Teaching Objectives Is Not in Place, and the Excavation of Textbooks Is Insufficient}

Textbooks are the main carriers for the realization of teaching objectives, and teaching objectives are the main basis for the compilation of textbooks. Teaching goal is a system containing knowledge, ability and values. "The goal of rule of law education is to enable students to know and understand some legal departments and legal provisions and experience the process of rule of law on the basis of understanding knowledge in the learning process. In this way, students' thinking ability of rule of law can be better cultivated, and the socialist concept of rule of law can be rooted in students' minds." [1] On the one hand, the rule of law education in ideological and political courses of middle schools is often carried out around knowledge objectives, but pays insufficient attention to ability objectives and values objectives, and the proportion of contents is not reasonable enough. In particular, the cultivation of consciousness of rule of law is not enough, and the realization of teaching objectives is not in place. Teachers often focus on the teaching of legal provisions in textbooks, but ignore the interpretation of the awareness of the rule of law, and even only require students to "memorize" the so-called key points for test, resulting in the rule of law education becoming boring words. On the other hand, the excavation of textbooks is insufficient. Teachers fail to fully excavate the integrating point between textbooks and the law of middle school students' physical and mental development, and also fail to fully excavate the coincidence point between textbooks and middle school students' learning and life. Therefore, middle school students' learning initiative can't be stimulated, and the rule of law education become interpretation mechanically.

\subsection{The Teaching Methods Are Monotonous and the Teaching Abilities Are Uneven}

The teaching effect largely depends on the teaching methods. With the use of appropriate teaching methods, middle school students' learning enthusiasm and interest can be stimulated. The teaching method of rule of law education in ideological and political course of middle schools should not only meet the law of middle school students' physical and mental development, but also meet the theoretical and abstract requirements of legal knowledge and legal consciousness, so as to realize the internalization and externalization of legal knowledge and legal consciousness. On the one hand, this teaching method is still dominated by teachers' one-way indoctrination, and the teaching content is basically limited to some legal provisions, which fails to form an active and two-way interactive teaching mechanism, and is not close to the learning and life of middle school students. "The classroom teaching with teachers as the leadership and students as passive receivers makes it difficult for students to resonate with the content of the already unfamiliar legal system, and also conflicts with the practicality of the law itself, which directly affects the effect of rule of law education." [2] On the other hand, the professional background of ideological and political teachers is complex, many people learn and apply immediately or repeat what the book says, and there are few legal graduates and few systematic training courses, 
resulting in teachers with insufficient professional knowledge and uneven teaching ability.

\subsection{There Are Defects in the Evaluation Mechanism and the Evaluation System Has Not Been Established}

True and effective evaluation plays an important role in feedback, guidance and motivation. It is a method to evaluate the process and effect of teaching and learning according to teaching objectives. "The success of a class depends not only on wonderful teaching languages carefully designed by teachers in advance, but also on teachers' teaching evaluation full of educational wit in the process of two-way communication between teachers and students." [3] The evaluation mechanism of rule of law education in ideological and political class of middle schools focuses on teaching and ignores students' quality and ability, especially students' awareness of the rule of law. On the one hand, the evaluation criteria are mainly students' knowledge mastery, which is mainly reflected in students' test scores. There is a misunderstanding of emphasizing results over process and teachers over students. On the other hand, the evaluation system has not been established. Therefore, it is impossible to comprehensively evaluate the students' usual performance, examination results and awareness of the rule of law.

\section{THOUGHTS ON THE IMPROVEMENT OF THE RULE OF LAW EDUCATION IN IDEOLOGICAL AND POLITICAL COURSES OF MIDDLE SCHOOLS}

The three elements of textbooks, teaching and evaluation constitute the procedural closed loop of the general curriculum, which is also the logical starting point to improve the progressive rule of law education in the ideological and political course of middle school. The ideological and political teachers of middle schools should fully sort out the rule of law education content of textbooks according to the requirements of systematic teaching objectives. On this basis, with the comprehensive use of a variety of teaching methods and the construction of the rule of law culture in campus, teaching methods will be innovated. At the same time, the competent education departments and schools shall give full play to the organizational role of learning and training. Finally, the effect of rule of law education in ideological and political course of middle schools should be tested by scientific evaluation system.

\subsection{Textbook Element: Achieving the Three-level Teaching Objectives and Fully Sorting out the Rule of Law Education Content of the Textbook}

Based on teaching materials, the rule of law education in ideological and political courses of middle schools should achieve the three-level teaching objectives of knowledge, ability and values. Knowledge objective refers to understanding basic legal concepts, basic legal knowledge and basic legal provisions; ability objective refers to having certain self-control and discrimination ability, being able to adapt to the society rationally and independently, and being able to put legal knowledge into practice; and value objective is at the highest level, which refers to cultivating middle school students' awareness of the rule of law. According to "Ideological and Political Curriculum Standard for Senior High Schools" (revised in 2020, hereinafter referred to as the curriculum standard) formulated by the Ministry of Education, the "awareness of the rule of law" is one of the core qualities of the discipline. On the one hand, teachers should fully sort out the content of rule of law education in ideological and political textbooks according to the curriculum standards, and pay attention to the text content and the auxiliary text content, i.e. relevant supplementary examples, illustrations, documents, etc. In addition, the tabular enumeration method can be used to find out the legal knowledge points in the textbooks, mark the corresponding legal provisions, and clarify the relationship and internal logic between the legal knowledge points, so as to avoid disorder and fragmentation. "We can break through the barriers of textbook content of each grade and text content of different units by constructing the knowledge map of the rule of law, and place the knowledge points in the whole discipline system to lay a foundation for the overall teaching design." [4] On the other hand, elective textbooks are the useful supplements to compulsory textbooks, and teachers should fully sort out the rule of law education content of elective textbooks. Teachers can appropriately introduce the basic theory of law, basic knowledge of civil law and basic knowledge of criminal law in elective textbooks, expand students' fields of study and enrich their legal knowledge structure. 


\subsection{Teaching Element: Innovating Teaching Methods and Improving Teaching Ability}

First, it is required to use case teaching method to guide students to integrate theory with practice. Compared with monotonous teaching of legal provisions, it is suggested to introduce cases into the teaching of ideological and political course, so as to realize the unity of knowledge memorization, ability training and values training. Teachers should select authentic and enlightening cases according to the law of middle school students' physical and mental development, and carry out communication, discussion, analysis and summary. Second, it is necessary to use the debate teaching method to guide students to apply what they have learned. With the use of the debate teaching method, the subjectivity of students is highlighted, students are divided into several groups to debate on specific topics, and finally, teachers make the comments and summary, so as to improve students' learning initiative and knowledge application ability. Third, it is suggested to use situational teaching method to stimulate students' interest in learning. According to the research of emotional psychology, individual emotion has the functions of driving, strengthening and regulating cognitive activities. Situational teaching method is used to create a teaching situation, trigger students' positive and healthy emotional experience, make students better integrate into the classroom and improve their learning initiative. In the rule of law education of ideological and political course in middle school, the ways of creating teaching situation mainly include video reproduction, physical demonstration, music rendering, theater experience and so on. Teachers should use the teaching situation to impart the content of teaching materials to students within a certain time, and the importance of legal knowledge and legal awareness will be highlighted. Fourth, it is necessary to create the rule of law culture of campus combined with the actual conditions. Schools can build a law publicity corridor, place law publicity signs, build a mock court place and hold legal knowledge lectures to immerse students in a strong campus law culture. Finally, ideological and political teachers in middle school should strengthen the learning and training of relevant professional knowledge and professional ability to improve their teaching ability. The professionalism of legal knowledge is very strong, which requires ideological and political teachers not only to have high political quality and professional ethics, but also to have certain professional knowledge and professional ability. The competent education departments and schools shall adopt the combination of offline and online learning and training methods, give full play to the role of the network teaching platform, require teachers to complete a certain number of network class hours, and ensure the full coverage of ideological and political teachers.

\subsection{Evaluation Element: Using a Variety of Evaluation Mechanisms and Building a Scientific Evaluation System}

First, it is suggested to use the process evaluation mechanism. The evaluation content of the process evaluation mechanism is on the usual performance of middle school students in the rule of law education of ideological and political course, including classroom performance, homework and related campus activities, and focusing on the assessment of students' learning attitude. Second, it is required to use summative evaluation mechanism. The evaluation content of the summative evaluation mechanism is on the learning effect of students after completing the course study, and the examination score is the main evaluation index, focusing on the evaluation of students' legal knowledge and the ability to use legal knowledge to solve practical problems. The examination may be carried out in the forms of written examination, oral examination or mixed examination. Third, it is necessary to use formative evaluation mechanism. The evaluation content of the formative evaluation mechanism is on the status of middle school students' awareness of the rule of law in the rule of law education of ideological and political course. And it can be carried out in many forms, such as case analysis, group discussion, situation simulation, questionnaire survey, visiting experience and so on, focusing on the assessment of students' ideology and values. On the whole, process evaluation mechanism, summative evaluation mechanism and formative evaluation mechanism jointly build a student-centered scientific evaluation system. "It is suggested to promote students' development through teaching, sublimate students' emotions in the process of learning, pay more attention to students' thoughts and behaviours at ordinary times, combine quantitative evaluation based only on scores with illustrative qualitative evaluation, and turn the evaluation focusing on the score of ideological and political courses in middle schools as a result to the daily growth process of middle school students." [5] Therefore, the formative 
evaluation mechanism corresponds to the value objective at the highest level, and cannot be confined to the qualitative and rigid score, but should pay attention to describing and evaluating the students' individual awareness of the rule of law, and put it into practice through scientific evaluation standards and quantitative indicators.

\section{CONCLUSION}

Recently, according to "the eighth five-year plan for the national education system to carry out publicity on the rule of law education (2021-2025)" issued by the Ministry of Education, it is suggested to promote the full development of rule of law courses in colleges, primary and secondary schools, and appropriately increase the proportion of legal knowledge in the senior high school entrance examination and college entrance examination, thus marking a new level of rule of law education in ideological and political courses of middle schools. There is no doubt that the existence and development of human society need to be maintained by rationality and rules, and the rule of law is synonymous with rationality and rules. The rule of law is not only an important symbol of modern civilization, but also an important achievement of human civilization. From state institutions to individual words and deeds, they need to operate within the framework of the rule of law. Therefore, it is the due meaning of the times calling for the rule of law to let middle school students thrive under the context of the rule of law.

\section{AUTHORS' CONTRIBUTIONS} Cao.

This paper is independently completed by Zhiyu

\section{REFERENCES}

[1] Shang Jiubin. The practice of implementing the rule of law education in ideological and moral courses [J]. Ideology and Politics Teaching, 2016(8): 14. (in Chinese)

[2] Qian Tongtong. Analysis of the problems and countermeasures in the education of rule of law in middle school [J]. Politics, History and Geography in Middle School (Teaching Guidance), 2021(3): 41. (in Chinese)

[3] Kong Jianmin. On the evaluation of ideological and political classroom teaching in middle schools [J]. Learning week, 2015(8): 170. (in Chinese)
[4] Wang Yanyan. Research on the Problems and Effective Strategies of the Rule of Law Education for Junior Middle School Students - Based on the Ideological and Moral Course Renaming Morality and Rule of Law [D]. Liaocheng University, 2018: 24. (in Chinese)

[5] Sun Jing. On the teaching evaluation of ideological and political courses in middle schools [J]. Educational Modernization, 2015 (11): 213. (in Chinese) 